\title{
Glycosylated Metalloporphyrins as Neutral Carriers for PVC Membrane Electrodes
}

\author{
Zhi-Zhang LI,*** Xiao-Bing Zhang, ${ }^{* \dagger}$ Can-Cheng Guo,* Guo-Li Shen,* and Ru-Qin YU* \\ *College of Chemistry and Chemical Engineering, Hunan University, Changsha 410082, P. R. China \\ **Teachers' College of Lingling, Yongzhou, Hunan 425000, P. R. China
}

\begin{abstract}
In this paper, the synthesis of a novel ionophore, chloro[5,10,15,20-tetrakis[2-(2,3,4,6-tetraacetyl- $\beta$-D-glucopyranosyl)-1$O$-phenyl]porphinato]manganese $(\mathrm{MnT}(o$-glu $) \mathrm{PPCl})$, and its application as a neutral carrier for a $\mathrm{PVC}$ membrane electrode are described. The $\mathrm{MnT}(o$-glu $) \mathrm{PPCl}$-based PVC membrane electrode shows a potentiometric responses to $\mathrm{SCN}^{-}$over a concentration range of $3.4 \times 10^{-7}-1.0 \times 10^{-1}$ mol L-1 with a Nernstian slope and a response time of $20 \mathrm{~s}$. The electrode exhibits an anti-Hofmeister selectivity toward $\mathrm{SCN}^{-}$with respect to common coexisting anions. As active materials, $\mathrm{MnT}(o$-glu $) \mathrm{PPCl}$ shows better selectivity toward $\mathrm{SCN}^{-}$than chloro(tetraphenylporphinato)manganese $(\mathrm{MnTPPCl})$. The effect of the electrode membrane compositions has been studied and the experimental conditions were optimized. The electrode was applied to the determination of $\mathrm{SCN}^{-}$in body fluids with satisfactory results.
\end{abstract}

(Received September 25, 2001; Accepted December 25, 2001)

\section{Introduction}

Recent years have seen growing interest in the chemistry of carbohydrate-porphyrins owing to their special properties. ${ }^{1-4} \mathrm{~A}$ number of carbohydrate-porphyrin compounds were synthesized as promising candidates for application to photodynamic therapy (PDT) against tumors owing to their specific interaction with biomembranes. ${ }^{5-7}$ Metallic complexes of these compounds were reported as active catalysts for alkene epoxidation with asymmetric induction, ${ }^{8-11}$ as well as alkane oxidation. ${ }^{12,13}$ The specific structures of carbohydrate-porphyrin compounds show that they might serve as useful ionophores in analytical chemistry for molecular recognition. This paper describes the synthesis and preliminary application of these compounds as electro-active materials for ion-sensitive electrodes.

The search for, or synthesis of, new carriers with antiHofmeister selectivity patterns has been the focus of the research of electro-chemical sensors. Among anti-Hofmeister materials, metalloporphyrins have attracted a great deal of interest owing to the diversity of their structures and interaction between the central metal and the analyte anions. ${ }^{14-18}$ Few metalloporphyrin-based $\mathrm{SCN}^{-}$sensitive electrodes were also reported. ${ }^{19,20}$ However, the selectivity of these electrodes was rather limited. This paper reports on the use of several metalloporphyrins as electroactive materials for preparing $\mathrm{SCN}^{-}$ sensitive electrodes. Due to its special structure, the MnT (oglu) PPCl-based electrode shows better selectivity toward $\mathrm{SCN}^{-}$ than that of $\mathrm{MnTPPCl}$, which in turn is better than those electrodes reported in the literature. The electrode was applied to the determination of $\mathrm{SCN}^{-}$in human urine samples.

\footnotetext{
† To whom correspondence should be addressed.

E-mail: xbzxbz@21cn.com
}

\section{Experimental}

Reagents

All of the chemicals used were of analytical reagent grade. Twice-distilled water was used throughout all experiments. Before used, dichloromethane and benzaldehyde were subjected to simple distillation from $\mathrm{K}_{2} \mathrm{CO}_{3}$. Pyrrole was distilled at atmospheric pressure from $\mathrm{CaH}_{2}$. High-molecular-weight poly(vinyl chloride) (PVC), dioctyl phthalate (DOP), dibutyl phthalate (DBP), and dioctyl sebacate (DOS) were purchased from Shanghai Chemicals (Shanghai, China) and used as received. $o$-Nitrophenyl octyl ether $(o$-NPOE) was prepared according to a reported method. ${ }^{21} \mathrm{MnTPPCl}$ was prepared according to a documented procedure ${ }^{22}$ and checked by elementary analysis, UV-VIS and IR spectroscopy.

Synthesis of $\mathrm{T}(\mathrm{o}-\mathrm{glu}) \mathrm{PPH}_{2}$

Following a known procedure, ${ }^{12} 4.5 \mathrm{~g}$ of freshly synthesized $o$-(2,3,4,6-tetraacetyl- $\beta$-D-glycosylphenyl)benzaldehyde, $0.7 \mathrm{~g}$ of freshly distilled pyrrole and $0.5 \mathrm{~mL}$ of $\mathrm{BF}_{3} \cdot \mathrm{Et}_{2} \mathrm{O}$ were dissolved in $800 \mathrm{~mL}$ of $\mathrm{CH}_{2} \mathrm{Cl}_{2}$ to form a reaction mixture, and stirred under a nitrogen atmosphere at room temperature for 24 $\mathrm{h}$. After the addition of $1.7 \mathrm{~g}$ of dichlorodicyanobenzoquinone, the mixture was refluxed for a further $2 \mathrm{~h}$, and then $10 \mathrm{~g}$ of silica was added and the solvent evaporated. The residue retained on silica was purified by column chromatography (silica, $\mathrm{CH}_{2} \mathrm{Cl}_{2}$ /acetone 7:1). After removing the solvent, $1.03 \mathrm{~g}$ $(20.5 \%)$ of $\mathrm{T}(o$-glu $) \mathrm{PPH}_{2}$ was obtained. Anal. Calcd. for $\mathrm{C}_{100} \mathrm{H}_{102} \mathrm{~N}_{4} \mathrm{O}_{40}$ : C, 60.1; H, 5.1; N 2.8. Found: $\mathrm{C}, 59.8 ; \mathrm{H}, 5.0$; $\mathrm{N}$, 3.1. UV-VIS $\left(\mathrm{CH}_{2} \mathrm{Cl}_{2}\right): \lambda_{\max }: 418.0,516.0,544.5,587.5$, $654.0 \mathrm{~nm} . \quad{ }^{1} \mathrm{HNMR}\left(\mathrm{CDCl}_{3}\right)(\mathrm{ppm}): 8.84(4 \mathrm{H}$, pyrrole $), 8.67$ (4H, pyrrole), $7.86(4 \mathrm{H}$, benzene) $7.78(4 \mathrm{H}$, benzene $), 7.70(4 \mathrm{H}$, benzene), $7.51(4 \mathrm{H}$, benzene $), 4.79(4 \mathrm{H}$, glucose $), 4.68(4 \mathrm{H}$, glucose $), 4.62(4 \mathrm{H}$, glucose $), 4.14(12 \mathrm{H}$, glucose $), 3.68(4 \mathrm{H}$, glucose), $-1.20--0.25,0.5-1.3,1.51-2.19$ (48H, $\left.\mathrm{CH}_{3} \mathrm{CO}-\right)$, 


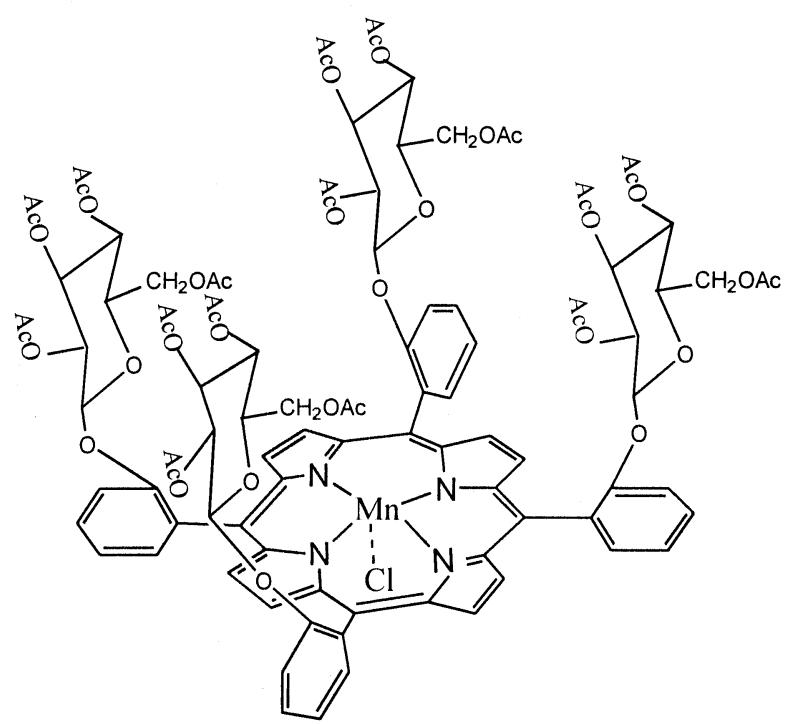

Fig. 1 Structure of glycosylated metalloporphyrin.

\section{$-2.81(2 \mathrm{H}, \mathrm{NH})$.}

The structure of glycosylated porphyrin is shown in Fig. 1.

\section{Synthesis of MnT(o-glu)PPCl}

A solution of $200 \mathrm{mg}$ of $\mathrm{T}(\mathrm{o}$-glu $) \mathrm{PPH}_{2}$ in $50 \mathrm{~mL}$ of DMF was stirred under refluxing with $1.0 \mathrm{~g}$ of $\mathrm{MnCl}_{2} \cdot \mathrm{H}_{2} \mathrm{O}$ for $6 \mathrm{~h}$. TLC (silica gel, $\mathrm{CH}_{2} \mathrm{Cl}_{2}$ ) showed a complete disappearance of the starting material and UV-VIS spectroscopy showed the absence of a nonmetallized porphyrin ring. After evaporation of the solvent in a vacuum, column chromatography afforded $170 \mathrm{mg}$ (79\%) of MnT(o-glu)PPCl. UV-VIS $\left(\mathrm{CH}_{2} \mathrm{Cl}_{2}\right): \lambda_{\max }: 399,426$, $510,575,654 \mathrm{~nm}$.

\section{Apparatus}

PVC membrane electrodes were prepared according to a procedure of Craggs et al..$^{23}$ The optimized membrane composition consists of $2 \%$ active materials, $66 \%$ solvent mediator and $32 \%$ PVC. The electrodes were conditioned in an aqueous solution of $0.1 \mathrm{~mol} \mathrm{~L}^{-1} \mathrm{NaSCN}$ for $12 \mathrm{~h}$. Potentiometric and $\mathrm{pH}$ measurements were carried out on a Model PHS-3E digital ion analyzer (Jiangshu Instruments, Jiangshu). The cell assemblies were of the following type:

$\mathrm{Hg}-\mathrm{HgCl}_{2}, \mathrm{KCl}$ (satd.)| sample solution | membrane | $0.01 \mathrm{~mol}$ $\mathrm{L}^{-1} \mathrm{KCl} \mid \mathrm{Ag}-\mathrm{AgCl}$

A standard solution of $\mathrm{SCN}^{-}$was obtained by serial dilution of a $0.1 \mathrm{~mol} \mathrm{~L}^{-1} \mathrm{NaSCN}$ solution and buffered with $0.01 \mathrm{~mol} \mathrm{~L}^{-1}$ of $\mathrm{KH}_{2} \mathrm{PO}_{4}-\mathrm{Na}_{2} \mathrm{HPO}_{4}$, the $\mathrm{pH}$ of which was adjusted with an $\mathrm{H}_{3} \mathrm{PO}_{4}$ or $\mathrm{NaOH}$ solution. IR spectra were recorded on a Perkin-Elmer Model 783 IR spectrophotometer and UV-VIS spectra on a Lambda 17 Perkin-Elmer spectrophotometer. A Perkin-Elmer 2400 elementary analyzer was used for elementary analysis.

\section{Results and Discussion}

\section{The effect of sensing materials}

Several electrodes were prepared using different porphyrins, including $\mathrm{MnT}(o$-glu)PPCl, MnTPPCl, FePPCl and CuTPP, with $o$-NPOE as a solvent mediator to study the effect of sensing materials. The results are given in Table 1 .

From Table 1 one can see that an electrode based on
Table 1 Response characteristics toward $\mathrm{SCN}^{-}$of electrodes based on different active materials

\begin{tabular}{clcc}
\hline $\begin{array}{c}\text { Electrode } \\
\text { no. }\end{array}$ & $\begin{array}{c}\text { Active } \\
\text { material }\end{array}$ & $\begin{array}{c}\text { Working concentration } \\
\text { range/mol L }\end{array}$ & $\begin{array}{c}\text { Slope } \\
\text { (mV/decade) }\end{array}$ \\
\hline 1 & MnTPPCl & $2.8 \times 10^{-7}-1.0 \times 10^{-1}$ & $58.5 \pm 1.5$ \\
2 & FeTPPCl & $5.2 \times 10^{-6}-1.0 \times 10^{-1}$ & $50.0 \pm 2.0$ \\
3 & CuTPP & sluggish response & - \\
4 & MnT $(o$-glu $) \mathrm{PPCl}$ & $3.4 \times 10^{-7}-1.0 \times 10^{-1}$ & $57.5 \pm 2.0$ \\
\hline
\end{tabular}

Table 2 Selectivity coeffecients, $\log K_{\mathrm{SCN}^{-}, \mathrm{i}}^{\text {pot }}$, for various interfering anions using a separate solution method

\begin{tabular}{ccccccc}
\hline $\begin{array}{c}\text { Interfering } \\
\text { anion }\end{array}$ & $\mathrm{ClO}_{4}^{-}$ & $\mathrm{I}^{-}$ & $\mathrm{NO}_{3}^{-}$ & $\mathrm{Br}^{-}$ & $\mathrm{NO}_{2}^{-}$ & $\mathrm{Cl}^{-}$ \\
\hline $\mathrm{E} 1 \log K_{\mathrm{SCN}}^{\mathrm{pot}-\mathrm{i}}$ & -2.31 & -1.24 & -3.73 & -3.05 & -2.75 & -3.91 \\
$\mathrm{E} 4 \log K_{\mathrm{SCN}^{-}, \mathrm{i}}^{\text {pot }}$ & -3.86 & -3.36 & -4.35 & -3.79 & -3.64 & -5.33 \\
\hline
\end{tabular}

E1, E4 mean electrode numbers to be 1 and 4 , respectively.

Table 3 Response characteristics toward $\mathrm{SCN}^{-}$of electrodes utilizing various plasticizers

\begin{tabular}{clcc}
\hline $\begin{array}{c}\text { Electrode } \\
\text { no. }\end{array}$ & Plasticizer & $\begin{array}{c}\text { Working concentration } \\
\text { range/mol L }\end{array}$ & $\begin{array}{c}\text { Slope } \\
\text { (mV/decade) }\end{array}$ \\
\hline 4 & $o$-NPOE & $3.4 \times 10^{-7}-1.0 \times 10^{-1}$ & $57.5 \pm 2.0$ \\
5 & DOP & $5.6 \times 10^{-6}-1.0 \times 10^{-1}$ & $53.5 \pm 1.5$ \\
6 & DBP & $3.2 \times 10^{-6}-1.0 \times 10^{-1}$ & $47.5 \pm 2.0$ \\
7 & DOS & $8.4 \times 10^{-6}-1.0 \times 10^{-1}$ & $44.5 \pm 1.0$ \\
\hline
\end{tabular}

Membrane composition for each electrode was 2:66:32 (MnT(o-glu)PPCl:plasticizer:PVC).

MnTPPCl shows better response characteristics than that of $\mathrm{FeTPPCl}$ in terms of the working concentration range and slope, while an electrode based on TPPCu shows sluggish nonregular responses. The role of the central metal in the electrode response mechanism is obvious. The order $\mathrm{Mn}-\mathrm{Fe}-\mathrm{Cu}$ is just opposite to the Irving-Williams order. In fact, the ligand field stabilization energy for $\mathrm{Mn}$ (III) is less than that for $\mathrm{Fe}$ (III) or $\mathrm{Cu}(\mathrm{II})$. One would expect that the Mn complex is the least stable compared to $\mathrm{Fe}$ and $\mathrm{Cu}$ complexes. However, according to Simon et al., ${ }^{24}$ the stability of the complex between the neutral carrier and the analyte ion should be intermediate, not necessarily the highest one. It has been well shown that the potentiometric response of metalloporphyrin derivatives toward the analyte anion is associated with the coordination action between the analyte anions and the central metal, as follows: ${ }^{15}$

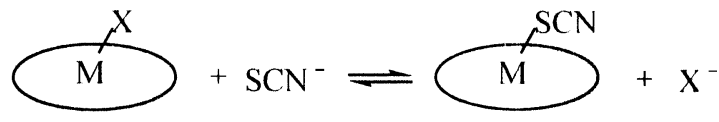

Here, the coordination ability of the central Mn of MnTPPCl with $\mathrm{SCN}^{-}$is the largest, while that of $\mathrm{TPPCu}$ is the least, because some complexation reactions of $\mathrm{Cu}$ (II) in analytical chemistry have a rather slow reaction rate, or are even irreversible. From Table 1 one can also see that MnT (o-glu) PPCl-based electrode shows a potentiometric response toward $\mathrm{SCN}^{-}$with a work concentration range and slope comparable to that of TPPMnCl. However, its selectivity toward $\mathrm{SCN}^{-}$is better than that of TPPMnCl (see Table 2). The effect of substitution on the benzene rings is distinct: the glucopyranosyl group bound at the benzene rings of $\mathrm{MnT}(o$-glu $) \mathrm{PPCl}$ formed a 


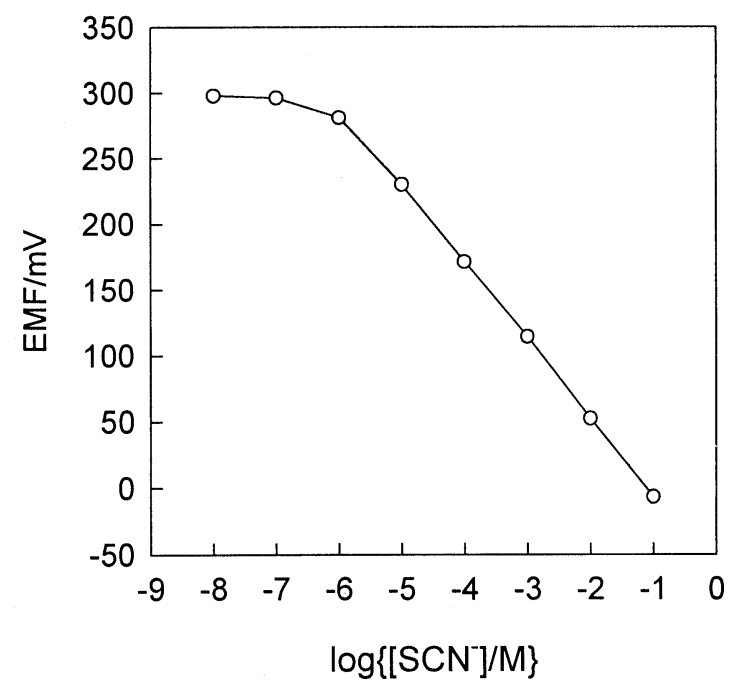

Fig. 2 Response characteristics of an electrode based on MnT (oglu) $\mathrm{PPCl}$.

hollow cube which might act as a molecular-recognition host for $\mathrm{SCN}^{-}$, on one hand (see Fig. 1); on the other hand, it might cause a steric hindrance for $\mathrm{SCN}^{-}$to approach the porphyrin. These results cause the MnT(o-glu)PPCl-based electrode to display similar response characteristics, but better selectivity (see Table 2) compared to that of MnTPPCl. All further studies were carried out on the $\mathrm{MnT}(o$-glu $) \mathrm{PPCl}$ based electrode.

\section{The effect of plasticizers}

Electrodes with different plasticizers, i.e. DOP, DBP, DOS and $o$-NPOE, were prepared using $\mathrm{MnT}(o$-glu $) \mathrm{PPCl}$ as the active membrane component. The response characteristics of these electrodes are given in Table 3. The electrode with $o$ NPOE as the solvent mediator obviously has a better response for $\mathrm{SCN}^{-}$compared to the others. In an electrode preparation experiment we observed an obviously greater solubility of $\mathrm{MnT}(o$-glu $) \mathrm{PPCl}$ in $o$-NPOE compared to other solvents, which is favorable for the response performance.

\section{Response characteristics of the electrode}

Figure 2 shows the response curve of an electrode with an optimum membrane composition of [MnT $(o$-glu $) \mathrm{PPCl}: o$ NPOE:PVC $=2: 66: 32]$. The working concentration range covers from $3.4 \times 10^{-7}$ to $1.0 \times 10^{-1} \mathrm{~mol} \mathrm{~L}^{-1} \mathrm{SCN}^{-}$in a $\mathrm{KH}_{2} \mathrm{PO}_{4}-\mathrm{Na}_{2} \mathrm{HPO}_{4}$-buffered solution $(\mathrm{pH}=5.2)$ with a slope of $57.5 \pm 2.0 \mathrm{mV}$ per decade of activity. The response time $\left(t_{90 \%}\right)$ for an $\mathrm{SCN}^{-}$concentration $\geq 1.0 \times 10^{-4} \mathrm{~mol} \mathrm{~L}^{-1}$ is as fast as $10 \mathrm{~s}$; with a concentration lower than $1.0 \times 10^{-4} \mathrm{~mol} \mathrm{~L}^{-1}$, it is less than $20 \mathrm{~s}$. It seems that the response involves a rapid reversible anion-exchange process at the solution/membrane interface. The standard deviations of the electrode potential and slope over a period of $12 \mathrm{~h}$ for 20 measurements in $1.0 \times 10^{-3} \mathrm{~mol} \mathrm{~L}^{-1}$ $\mathrm{SCN}^{-}$were found, respectively, to be $1.5 \mathrm{mV}$ and $1.2 \mathrm{mV}$. The electrode was dipped alternatively into stirred solutions of $1.0 \times$ $10^{-3} \mathrm{~mol} \mathrm{~L}^{-1}$ and $1.0 \times 10^{-4} \mathrm{~mol} \mathrm{~L}^{-1} \mathrm{SCN}^{-}$over a period of $4 \mathrm{~h}$ for repeated measurements, which show standard deviations of the potential readings in these two solutions as $2.2 \mathrm{mV}$ and 1.4 $\mathrm{mV}$, respectively. There is no noticeable hysteresis of the electrode response. The electrodes were stored in a $0.1 \mathrm{~mol} \mathrm{~L}^{-1}$ $\mathrm{SCN}^{-}$solution when not in use. The electrodes worked well and no detectable change in the value of the slope, the working concentration range or the response time was found after they

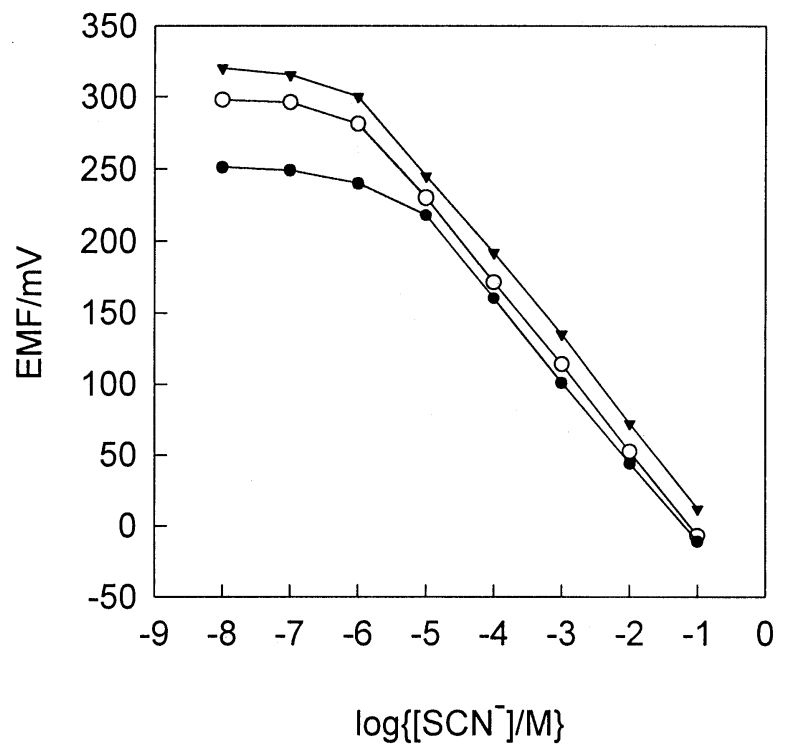

Fig. 3 Effect of the $\mathrm{pH}$ on the electrode's response at: $(\bullet) \mathrm{pH} 6.5$; (०) $\mathrm{pH} 5.2 ;$ ( $\mathbf{\nabla}) \mathrm{pH} 4.0$.

had been used for six months, which implies that the glycosylated metalloporphyrins used are stable in a membrane contacting with water.

\section{Selectivity}

The common coexisting cations did not cause any observable influence on the determination of $\mathrm{SCN}^{-}$. The selectivity coefficients, $\log K_{\mathrm{SCN}, \mathrm{i}}^{\mathrm{pot}}$, for a number of mono-valent anions were determined by a separate solution method according to an IUPAC recommendation. ${ }^{25}$ The results presented in Table 2 reveal that the electrode based on $\mathrm{MnT}(o$-glu $) \mathrm{PPCl}$ was fairly selective to $\mathrm{SCN}^{-}$over other anions. It exhibited the antiHofmeister selectivity sequence of anions in the following order: $\mathrm{SCN}^{-}>\mathrm{I}^{-}>\mathrm{NO}_{2}^{-}>\mathrm{Br}^{-}>\mathrm{ClO}_{4}^{-}>\mathrm{NO}_{3}^{-}>\mathrm{Cl}^{-}$, which is different from that of the $\mathrm{MnTPPCl}$ electrode, as well as electrodes reported in a reference. ${ }^{20}$ This selectivity pattern is thought to be caused by the cooperation of the aforementioned steric hindrance as well as the different coordinating capability of anions with the central metal of $\mathrm{MnT}(o$-glu $) \mathrm{PPCl}$.

\section{Effect of the $p H$}

The effect of the $\mathrm{pH}$ on the response characteristics of the MnT(o-glu)PPCl-based electrode is shown in Fig. 3. It seems that $\mathrm{SCN}^{-}$and $\mathrm{OH}^{-}$ions exist in competitive coordination with the central metal of $\mathrm{MnT}(o-\mathrm{glu}) \mathrm{PPCl}$. The $\mathrm{SCN}^{-}$ion shows a stronger coordination ability compared to that of the $\mathrm{OH}^{-}$ion. In the higher concentration section of $\mathrm{SCN}^{-}\left(10^{-4}-10^{-1} \mathrm{~mol}\right.$ $\mathrm{L}^{-1}$ ), the $\mathrm{pH}$ does not cause any obvious interference for the $\mathrm{SCN}^{-}$response. At a lower concentration level of $\mathrm{SCN}^{-}\left(10^{-7}\right.$ $10^{-4} \mathrm{~mol} \mathrm{~L}^{-1}$ ) with an increase in the $\mathrm{OH}^{-}$concentration, the $\mathrm{OH}^{-}$ion becomes the primary analyte ion. The response of the electrode for $\mathrm{SCN}^{-}$deviates from the linear one, especially at high $\mathrm{pH}$ values. According to Meyerhoff et al.,${ }^{14}$ the origin of the $\mathrm{pH}$ effect to this type of electrode can be attributed to the coordination of water molecules as axial ligands to the central metal of porphyrin complexes. The loss of a proton from a water molecule can yield a hydroxide-coordinated central metal showing a $\mathrm{pH}$ response. The experimental results show that a $\mathrm{KH}_{2} \mathrm{PO}_{4}-\mathrm{Na}_{2} \mathrm{HPO}_{4}$ buffer solution with a pH of 5.2 could provide the best response for the electrode. In subsequent 
Table 4 Comparison of the results of the electrode and colorimetric methods for the determination of $\mathrm{SCN}^{-}\left(\mathrm{mmol} \mathrm{L}^{-1}\right)$ in human urine samples

\begin{tabular}{lccccc}
\hline \multicolumn{1}{c}{ Sample no. } & 1 & 2 & 3 & 4 & 5 \\
\hline Electrode method $^{\mathrm{a}}$ & 0.27 & 0.79 & 0.16 & 0.55 & 0.63 \\
Colorimetric method $^{\mathrm{b}}$ & 0.28 & 0.77 & 0.17 & 0.57 & 0.60 \\
\hline
\end{tabular}

a. Direct potentiometry with the proposed electrode after 10-fold dilution of the sample with a buffer solution.

b. Urine samples were diluted 10-fold following the method of Butts et al. ${ }^{26}$

experiments, such a buffer solution was selected.

\section{Preliminary Analytical Application}

The electrode was applied to the determination of $\mathrm{SCN}^{-}$ion in human urine samples. The obtained results were compared with those obtained by the colorimetric method, ${ }^{26}$ as shown in Table 4. The concentration of $\mathrm{SCN}^{-}$, as determined by the electrode method, was in good agreement with that obtained by the conventional method. The MnT (o-glu) PPCl-based electrode seems to be useful for the determination of $\mathrm{SCN}^{-}$in actual samples. An obvious advantage of this method is the rather simple sample-preparation procedure for potentiometry with an electrode that requires just a ten-fold dilution of the sample with an appropriate buffer solution.

\section{Acknowledgements}

This work was supported by the National Science Foundation (Grants 20075006, 29975006 and 29735150), the Foundation for Technological Development of Machinery Industry and Science Commission of Hunan Province.

\section{References}

1. P. Maillard, J. L. Guerquin-Kern, M. Momenteau, and S. Gaspard, J. Am. Chem. Soc., 1989, 111, 9125.

2. K. Hermann, O. Stefan, and K. Daniela, Tetrahedron, 1996, 52,5441 .

3. D. Oulmi, P. Maillard, J. L. Guerquin-Kern, C. Huel, and M. Momenteau, J. Org. Chem., 1995, 60, 1554.
4. P. Maillard, J. L. Guerquin-Kern, C. Huel, and M. Momenteau, J. Org. Chem., 1993, 58, 2774.

5. I. Voszka, R. Galantai, P. Maillard, and G. Csik, J. Photochem. Photobiol. B: Biol., 1999, 52, 92.

6. R. Davoust, R. Granet, and P. Krausz, Tetrahedron Lett., 1999, 40, 2513.

7. F. Gabor, J. Szolnoki, K. Toth, A, Fekete, P. Maillard, and G. Csik, Photochem. Photobiol., 2001, 73, 304.

8. S. Vilain, A. Robert, P. Maillard, B. Meunier, and M. Momenteau, J. Mol. Catal. A: Chem., 1996, 113, 23.

9. S. Vilain, P. Maillard, and M. Momenteau, J. Mol. Catal. A: Chem., 1996, 113, 201.

10. S. Vilain, P. Maillard, and M. Momenteau, J. Chem. Soc. Chem. Commun., 1994, 1697.

11. P. Maillard, S. Vilain, C. Huel, and M. Momenteau, J. Org. Chem., 1994, 59, 2887.

12. X. B. Zhang, C. C. Guo, J. B. Xu, and R. Q. Yu, J. Mol. Catal. A: Chem., 2000, 154, 31.

13. C. C. Guo, X. B. Zhang, J. X. Song, and H. P. Li, Acta Chim. Sin., 2000, 58, 332.

14. N. A. Chaniotakis, S. B. Park, and M. E. Meyerhoff, Anal. Chem., 1989, 61, 566.

15. C. E. Kibbey, S. B. Park, G. DeAduyler, and M. E. Meyerhoff, J. Electroanal. Chem., 1992, 335, 135.

16. V. K. Gupta, A. K. Jain, and L. P. Singh, Anal. Chim. Acta, 1999, 379, 201.

17. X. B. Zhang, C. C. Guo, J. B. Xu, G. L. Shen, and R. Q. Yu, Analyst, 2000, 125, 867.

18. X. B. Zhang, C. C. Guo, L. X. Jian, G. L. Shen, and R. Q. Yu, Anal. Chim. Acta., 2000, 419, 227.

19. D. V. Brown, N. A. Chaniotakis, H. I. Lee, S. C. Ma, S. B. Park, M. E. Meyerhoff, R. J. Nick, and J. T. Groves, Electroanalysis, 1989, 1, 477.

20. S. Daunert, S. Wallace, A. Florido, and L. G. Bachas, Anal. Chem., 1991, 63, 1676.

21. E. C. Horning, "Organic Synthesis, Coll", 1959, Vol. 3, Wiley, New York, 140.

22. G. D. Dorough, J. R. Miller, and F. M. Hevnnekens, J. Am. Chem. Soc., 1951, 73, 4314.

23. A. Craggs, G. J. Moody, and J. D. R. Thomas, J. Chem. Educ., 1997, 51, 541.

24. E. Pretsh, D. Amman, and W. Simon, Research/Development, 1974, 25, 20.

25. IUPAC, Pure Appl. Chem., 1976, 48, 129.

26. W. C. Butts, M. Kuehneman, and G. M. Widdowson, Clin. Chem., 1974, 20, 1344. 